\title{
STRATEGI SUBSISTENSI DAN PEMILIHAN LOKASI HUNIAN PRASEJARAH DI SITUS YOMOKHO, SENTANI
}

\author{
The Subsistence Strategy and Prehistoric Settlement Location \\ Consideration at Yomokho, Sentani
}

\author{
Hari Suroto \\ Balai Arkeologi Jayapura \\ J1. Isele, Waena Kampung 99358 \\ mbah_toh@yahoo.com
}

Naskah diterima: 27-05-2013; direvisi: 10-08-2013; disetujui: 06-09-2013

\begin{abstract}
The research in the Sentani was concucted in the Yomokho site to understand the strategy of human occupation and subsistence. Reconesaince survey and excavation was adopted in this research. Focus group discussion was also adopted in this research to test the most adoptable heritage socialication for the school students. Pottery is the main artifacts found in this research. The analysis also found that the past communities in the Yomokho site lived the traditional house. The main factor to consider this site as the place to live in the past was based on the location that nearby the lake and sago forest.
\end{abstract}

Keywords: Yomokho Site, Settlement, Subsistence

\begin{abstract}
Abstrak
Penelitian di Kawasan Danau Sentani dilakukan di Situs Yomokho untuk mengetahui strategi pemilihan tempat tinggal manusia pendukung budaya Situs Yomokho, dan pola subsistensi. Untuk itu dalam penelitian ini dilakukan survei permukaan tanah dan ekskavasi. Hasil ekskavasi di Situs Yomokho diperoleh temuan berupa fragmen gerabah polos maupun hias. Berdasarkan analisis data diketahui bahwa fragmen gerabah hanya ditemukan di lapisan tanah bagian atas yang berwarna hitam. Kondisi Bukit Yomokho berupa lereng bukit yang miring. Diasumsikan manusia pendukung Situs Yomokho tinggal di rumah panggung, tidak semua bagian bukit dipilih untuk mendirikan tempat tinggal, tetapi disesuaikan dengan kondisi lereng bukit dan kondisi tanah. Pemilihan Situs Yomokho sebagai hunian masa lalu didasarkan pada lokasinya yang dekat dengan danau dan didukung oleh keberadaan hutan sagu.
\end{abstract}

Kata kunci: Situs Yomokho, Hunian, Subsistensi

\section{PENDAHULUAN}

Danau Sentani terletak di Kabupaten Jayapura, Papua. Letak posisi geografis $2^{0} 33^{\prime}$ $-2^{0} 41^{\prime}$ LS dan $10^{\circ} 38^{\prime}$ BT. Merupakan danau vulkanik, diantara pegunungan Cycloop. Danau Sentani memiliki luas 9.360 ha, dengan kedalaman rata-rata $24,5 \mathrm{~m}$. Perkampungan penduduk tersebar di tepi danau dan pulaupulau kecil di tengah danau.

Berdasarkan cerita rakyat Sentani, menyatakan bahwa nenek moyang mereka berasal dari Papua New Guinea yang bermigrasi untuk mencari wilayah baru. Terdapat tiga tempat di wilayah Sentani sebagai kampung tua atau kampung awal yang ditempati leluhur mereka sebelum menyebar lebih luas yaitu:

1. Bukit Yomokho, dalam perkembangannya kemudian mereka pindah ke Pulau Ohei (Kampung Asei), Ayopo Kecil, Waena, 
dan Yoka.

2. Pulau Ajau (Kampung Ifar Besar), dan kemudian sebagian pindah ke Ifar Kecil, Sibaobai, Yabuai, Sereh, Puyoh Kecil

3. Pulau Yonokhom (Kampung Kwadeware), dalam perkembangannya kemudian sebagian pindah ke Doyo, Sosiri, Yakonde, dan Dondai (Dwiastoro, 2009: 11).

Pada April 2010 Balai Arkeolog Jayapura melakukan eksplorasi arkeolog prasejarah di Kawasan Danau Sentani, ha ini dilatar belakangi oleh informasi dar masyarakat bahwa di Bukit Yomokho, Sentani, pekerja yang sedang meratakan lereng bukit dengan bulldozer, tanpa sengaja menemukan deposit cangkang molusk danau, cangkang moluska laut, fragmen tulang manusia, dan pecahan gerabah dari berbagai jenis. Selain itu juga ditemukan bekas tiang rumah panggung berbahan kayu soang (Xanthostemon $\mathrm{sp}$.)

Dalam penelitian ini berhasil menemukan situs Situs Yomokho. Situs Yomokho berada di wilayah Kampung Harapan berjarak kurang lebih 200 meter dar okasi Festival Danau Sentani. Hasil observas Balai Arkeologi Jayapura di situs Yomokho, berhasil menemukan sisa-sisa tulang manusia fragmen gerabah, dan singkapan potongan bukit dengan sejumlah deposit cangkang moluska yang banyak (Tim penelitian, 2010).

Hasil observasi ini kemudian pad tahun 2011 ditindaklanjuti dengan melakukan ekskavasi di Situs Yomokho, bertujuan untuk memperoleh gambaran jumlah dan keragaman tinggalan, kedalaman lapisan budaya dan jenis lapisan tanah (Suroto et al., 2011). Pemilihan kotak test pit dilakukan secara selektif (sampling) dengan beberapa pertimbangan logis, seperti kepadatan konsentrasi temuan permukaan; keadaan permukaan tanah; posisi kotak pada situs; dan diperkirakan dapat menghasilkan data yang ingin diketahui.

Kegiatan ekskavasi dimaksudkan untuk memperoleh sisa-sisa aktifitas manusi waktu yang telah lewat, terekam dalam lapisan-lapisan di bawah tanah, sehingga yang terjadi di situs dapat direkonstruksi. Dalam konteks ini, kajian terhadap situs dapat memberikan dimensi ruang yang dapat memperjelas batas-batas gerak aktifitas cara hidup manusia. Situs tidak hanya sekedar tempat atau lokasi, tetap menjadi konsep yang memudahkan untuk memahami kerangka perilaku manusia $\mathrm{d}$ situs tersebut (Said dan Utomo, 2006: 7).

Situs Yomokho merupakan daerah perbukitan, maka dalam pemilihan lubang uji, lokasi kotak tespit pertama (TP1) dipilih berada di tengah atas bukit yang memanjang dengan orientasi utara-selatan. Pemilihan lokasi ini selain karena posisinya, juga karena pada permukaannya dekat dengan konsentras batuan yang tersusun memanjang dari tengah bukit ke lereng bukit di sisi timur, serta terdapat beberapa fragmen gerabah. Kotak TP2 dipilih di singkapan tanah pada lereng ntrasi cangkang molusk danau.

Hasil ekskavasi di Situs Yomokho diperoleh temuan berupa fragmen gerabah hias maupun polos, manik-manik, cangkang moluska laut, cangkang moluska danau, arang, tulang binatang, dan tulang manusia, serta gambaran lapisan budaya yang cukup tebal. Temuan-temuan arkeologi tersebut dapat member interpretasi awal tentang perilaku dan pemanfaatan situs oleh manusia pendukungnya sebagai hunian.

Hal ini didukung pula oleh keadaan lingkungan sekitar situs seperti danau dan hutan sagu sebagai sumber memperoleh makanan. Di situs Yomokho, selain ekskavas juga dilakukan survei permukaan tanah yang hasilnya berupa jajaran batu yang dikaitkan dengan hasil ekskavasi memperkuat bahwa situs tersebut pada masa lalu merupakan pemukiman.

Ekskavasi tahun 2011 di Situs Yomokho baru pertama kali dan sebatas pembukaan kotak lubang uji, sehingga datanya masih sangat terbatas, hal ini berkaitan dengan interpretasi yang terbatas pula. Berdasarkan kuantitas data yang ditemukan dari TP1 dan
TP2 Situs Yomokho, menunjukkan bahwa data arkeologi lebih banyak di TP2 yang terletak di lereng bukit, hal ini diinterpretasikan pemukiman terletak di lereng Bukit Yomokho, tetapi ini baru interpretasi sementara karena bisa saja kepadatan temuan di lereng bukit disebabkan oleh longsoran dari atas, untuk itu guna mendukung interpretasi lebih luas, maka perlu dilakukan ekskavasi pada bagian Situs Yomokho yang mengandung lapisan konsentrasi cangkang moluska, maupun area yang diperkirakan sebagai pemukiman.

Berdasarkan uraian di atas maka permasalahan dalam penelitian ini adalah:

1. Bagaimana strategi pemilihan tempat tinggal manusia pendukung budaya Situs Yomokho?

2. Bagaimana strategi subsistensi manusia pendukung budaya Situs Yomokho?

Pada dasarnya tujuan ilmu arkeologi dimaksudkan untuk merekonstruksi sejarah kebudayaan, merekonstruksi cara hidup manusia masa lalu dan penggambaran proses perubahan kebudayaan (Binford, 1972: 78). Tujuan penelitian ini yaitu untuk mengetahui strategi pemilihan tempat tinggal manusia pendukung budaya Situs Yomokho dan untuk mengetahui strategi subsistensi manusia pendukung budaya Situs Yomokho.

Secara linguistik, bahasa Sentani dikelompokan dalam fila non-Austronesia, tetapi di Kawasan Danau Sentani terdapat ciri budaya Austronesia, diantaranya pembuatan gerabah di Kampung Abar, sistem kepemimpinan ondoafi yaitu sistem kepemimpinan yang diwariskan secara turun-temurun, tradisi kunyah pinang, tradisi minum cairan sadapan pohon kelapa, dan tradisi menghias tubuh dengan tato (Suroto, 2010:56).

Salah satu contoh bentuk adaptasi lingkungan terhadap pemukiman di wilayah Papua adalah pemukiman tradisional Suku Parim yang berada di Lembah Baliem. Berdasarkan kondisi alam setempat pembangunan rumah tradisional Suku Parim dipengaruhi tiga unsur, yaitu: geografis, geologis, dan iklim. Secara geografis, Lembah Baliem adalah sebuah dataran tinggi yang dikelilingi oleh gunung-gunung tinggi. Pada mulanya mereka memilih bagian lerenglereng gunung sebagai tempat pendirian rumah tinggal. Tujuannya untuk memudahkan penjagaan dari serangan musuh dan lahan di sekitar rumah dapat diolah sebagai lahan pertanian. Karena secara geologis, bagian lereng-lereng menyimpan kandungan kesuburan tanah yang tinggi. Lembah Baliem beriklim tropis lembab dan hawanya sejuk. Untuk menghindari hawa dingin, dinding bangunan rumah tradisional dibuat secara berlapis-lapis. Selain itu, di tengah-tengah bangunan biasanya dibuat perapian. Untuk mengurangi kelembababn tanah, lantai ditutupi rumput kering (Darmansyah, 2006 326-327).

Dalam upaya mempertahankan eksistensinya, manusia memerlukan tempat untuk berinteraksi dengan sesamanya maupun dengan lingkungannya. Makanan diperlukan dalam upaya mempertahankan hidupnya. Sehingga pemilihan tempat hunian dan jenis makanan dapat dipandang sebaga indikasi strategi adaptasi manusia pada masa lampau (Wiradnyana, 2011: 60). Proses adaptasi sendiri berjalan ketika manusia membandingkan pola tingkah laku yang telah dilakukannya dengan kondisi lingkungan yang dihadapi untuk kemudian disesuaikan.

Situs sebagai sumber data dalan arkeologi merupakan rangkaian ekosistem manusia dan lingkungannya, sehingga dalam pemilihan tempat tinggal selain didasarkan pada kondisi lingkungan juga bentang alam. Sejalan dengan hubungan antara manusia dengan alam lingkungannya, Subroto (1985:178) mengemukakan bahwa adanya hubungan antara pola pemukiman dengan gejala-gejala geografis seperti halnya keadaan topografis, tanah, vegetasi, dan zona curah hujan.

METODE

Pengumpulan data dilakukan dengan beberapa cara, yaitu: 1) studi pustaka, 
yaitu mengumpulkan data tertulis yang berhubungan dengan situs yang diteliti; 2) survei dengan cara mengamati permukaan tanah, untuk mendapatkan data arkeologi dalam konteksnya dengan lingkungan sekitarnya; dan 3) ekskavasi (Pusat Penelitia dan Pengembangan Arkeologi Nasional, 2008: 13-14). Ekskavasi di Situs Yomokho menggunakan metode box, teknik spit, interval kedalaman $10 \mathrm{~cm}$, luas kotak yang dipatok dan digali seluas $1 \times 1 \mathrm{~m}$. Kotak U62B19 digalidibukitbagian ats, duakotak U62B19 digatidi bukit bagian atas, dua kotak di lereng bukit sebelah tinur (kotak S11T38 dan S11139), dua kotak di lereng sebela barat (kotak S9B22 dan kotak S10B22). Kotak S11T38 dan S11T39 terletak pada koordinat S $02^{\circ} 35^{\prime} 53,2^{\prime \prime}$ E $140^{\circ} 34^{\prime} 26,1^{\prime \prime}$ elevasi 109 mdpl. Kotak S9B22 dan S10B22 berada pada S $02^{\circ} 35^{\prime}$ '53,3" E $140^{\circ} 34^{\prime} 24,1^{\prime \prime}$ dengan elevasi $108 \mathrm{mdpl}$. Kotak U62B19 terletak pada S $02^{\circ} 35^{\prime} 51,0^{\prime \prime} \mathrm{E} 140^{\circ} 34^{\prime} 23,7$ " dengan elevasi $123 \mathrm{mdpl}$.

Selanjutnya, data artefaktual dianalisis dengan cara mengamati ciri-ciri bentuk, ukuran, warna, teknologi, dan gaya. Sementara itu, untuk mengetahui fungs artefak dilakukan analisis kontekstual, yaitu mengamati hubungan artefak dengan temuan serta, baik artefak, ekofak, dalam satu matriks (association). Selain itu pengamatan juga dilakukan (provenience), sebaran temuan dalam kotak dan lapisan tanah (stratification).

\section{HASIL DAN PEMBAHASAN}

Hasil ekskavasi tahun 2012 pada lima kotak yang digali berupa fragmen gerabah berbagai jenis, sedangkan hasil survei permukaan di lingkungan sekitar Situs Yomokho yaitu fragmen gerabah, fragmen tulang manusia, cangkang moluska danau dan fragmen alat batu penokok sagu. Selain itu juga diketahui lapisan tanah dalam setiap kotak ekskavasi, serta batu sungai.

Alat batu penokok sagu ditemukan di sisi timur bukit Yomokho, berukura panjang $13,4 \mathrm{~cm}$, lebar 5,6 cm, dan tebal 5,3 $\mathrm{cm}$. Sebuah fragmen alat batu tokok sagu ditemukan di sisi barat bukit, alat batu ini berukuran panjang $5,1 \mathrm{~cm}$ lebar $4,5 \mathrm{~cm}$ dan tebal $3,5 \mathrm{~cm}$. Bahan kedu alat batu penokok sagu ini adalah batu sungai berwarna coklat.

Fragmen gerabah yang ditemukan menunjukkan bahwa berbahan tanah lia dengan temper pasir, berdasarkan analisis bentuk maka diketahui bahwa terdapat dua jenis gerabah yaitu tempayan dan periuk. Jenis tempayan diketahui dari ukuran dinding gerabah yang tebal, sedangkan gerabah jenis periuk diketahui dari ketebalan dinding gerabah yang tipis. Selain ketebalan dinding gerabah, bentuk gerabah juga dapat diketahui dari bentuk dan orientasi tepian.

Ekofak yang didapatkan dari survei permukaan yaitu cangkang moluska danau. Jenis moluska danau yang ditemukan yaitu moluska danau kelas gastropoda famili littorinidae. Cangkang moluska ini ditemukan pada sisi bukit sebelah timur, terlihat pada potongan lereng bukit akibat pelebaran jalan, berdasorkan pengamatan konsentrasi cangkang moluska danau ini hanya terdapat pada lapisan tanah berwarna hitam yang tebal. Berdasarkan temuan berupa deposit sisa-sisa makanan dalam jumlah besar yaitu cangkang moluska danau kelas gastropoda famili littorinidae mengindikasikan bahwa moluska danau telah dikonsumsi sebagai makanan utama.

Selain itu, temuan tulang binatang jenis tikus tanah (pogonomelomys), kuskus (phalanger orientalis), dan tulang ikan menunjukkan bahwa terdapat beberapa variasi jenis makanan yang dikonsumsi. Ketrampilan tertentu diperlukan untuk memperoleh jenis bahan makanan tersebut. Oleh karena itu, dapat diasumsikan bahwa manusia pendukung situs Yomokho telah mengenal teknik-teknik dalam berburu dan menangkap ikan.

Fragmen tulang manusia juga ditemukan dalam kondisi rapuh, pada longsoran tanah bukit yang berwarna hitam. Pengamatan terhadap konteks temuan fragmen tulang manusia ini adalah berkonteks dengan lapisan tanah warna hitam, yang bercampur dengan lapisan cangkang moluska danau dan fragmen gerabah. Tulang manusia yang ditemukan menunjukkan diperkirakan manusia dikuburkan tidak jauh dari pemukiman mereka. Temuan fragmen gerabah terletak dibawah tulang manusia, hal ini mengindikasikan bahwa gerabah tersebut berfungsi sebagai bekal kubur.

Lapisan tanah kotak yang digali pada kotak S11T39 dan kotak S11T38 menunjukkan bahwa lapisan tanah bagian atas berwarna hitam, pada lapisan ini fragmen gerabah ditemukan. Lapisan selanjutnya adalah tanah liat berwarna merah bercampur batu, lapisan selanjutnya didominasi oleh batu. Lapisan tanah pada ketiga kotak ekskavasi lainnya menunjukkan yang sama yaitu bagian atas berupa lapisan berwarna hitam dengan temuan gerabah, tetapi lapisan selanjutnya tidak ditemukan tanah liat berwarna merah, lapisan selanjutnya didominasi oleh tanah pelapukan batu.

Keberadaan gerabah di Situs Yomokho mengindikasikan gerabah ini merupakan bukti pertukaran atau perdagangan yang dilakukan oleh manusia pendukung situs Yomokho. Keberadaan gerabah juga menggambarkan hubungan manusia pendukung situs Yomokho dengan komunitas lain. Pola hias gerabah dari situs Yomokho memiliki kesamaan dengan gerabah dari Gua Skouw Mabo Jayapura, Gua Lachitu dan Gua Taora di Vanimo, Papua New Guinea. Pengamatan terhadap bahan artefak gerabah dan perbandingan dengan jenis tanah di situs Yomokho, tidak memiliki kesamaan sehingga dapat dikatakan bahwa gerabahgerabah tersebut didatangkan dari luar.

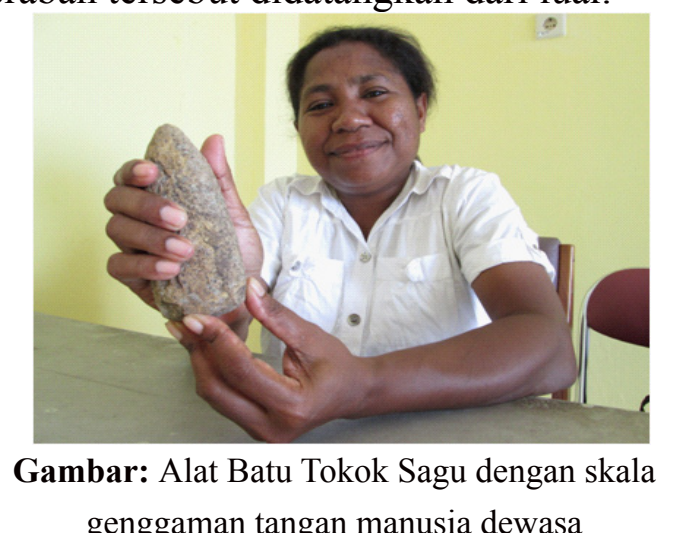

genggaman tangan manusia dewasa

(Sumber: Dokumen Pribadi)
Temuan artefak alat batu tokok sagu, mengindikasikan bahwa pendukung situs Yomokho mengolah dan mengonsumsi sagu, hal ini didukung oleh lingkungan sekitar Situs Yomokho berupa hutan sagu serta keberadaan artefak gerabah, diperkirakan gerabah jenis periuk untuk memasak air guna membuat papeda, sedangkan gerabah jenis tempayan untuk menyimpan tepung sagu.

Ekskavasi yang dilakukan di kotak U62B19, tepat di ujung struktur jalan batu, diketahui lapisan struktur jalan batu berada di lapisan atas sedangkan lapisan di bawahnya berupa tanah humus hitam, hal ini mengindikasikan bahwa batu-batu ini sengaja disusun oleh pendukung Situs Yomokho.

Pengamatan terhadap lapisan tanah dari kotak ekskavasi baik yang digali tahun 2011 maupun 2012 menunjukkan bahwa apisan tanah di area Situs Yomokho berbeda. Ketebalan tanah warna hitam dari kotak yang digali di Situs Yomokho berbeda, artefak gerabah ditemukan di lapisan tanah warna hitam, hal ini mengindikasikan bahwa aktivitas pendukung Situs Yomokho banyak dilakukan di lahan dengan lapisan tanah warna hitam tebal.

Bentuk batu yang bulat dengan ukuran kecil yang ditemukan di Situs Yomokho, diperkirakan batu-batu ini berfungsi sebagai peluru dalam berburu. Selain itu dengan adanya temuan batu sungai, membuktikan bahwa batu-batu ini sengaja dibawa ole manusia pendukung situs Yomokho, serta diperkirakan jelajah manusia pendukung Situs Yomokho menjangkau sungai-sungai di daerah Gunung Cycloop.

Dengan melihat kondisi lingkungan situs dan persebaran temuan arkeologiny menggambarkan bahwa situs Yomokho sebagai situs hunian terbuka. Jika ditinjau dari lokasi situs yang berada dekat dengan Danau Sentani, menunjukkan bahwa manusia pendukungnya telah memanfaatkan sumberdaya yang ada di lingkungan setempat seperti siput danau dan sagu sebagai sumber bahan makanan, dan untuk pengolahan makanan ditunjang oleh keberadaan gerabah 
sebagai wadah makanan.

Pemilihan Situs Yomokho sebagai area pemukiman mempertimbangkan lokasinya yang dekat dengan sumber bahan makanan (hutan sagu, danau sebagai sumber fauna) dan dekat dengan sumber air (danau). Selain itu pemilihan lokasi berkaitan dengan keamanan hunian, lokasi yang berada di bukit memudahkan memantau gerakan musuh, serta lokasi yang tinggi berkaitan juga dengan upaya mengindari dari serangan malaria.

Temuan cangkang moluska danau mengindikasikan pendukung situs Yomokho mengkonsumsi siput danau, hal ini didukung oleh keberadaan situs Yomokho di tepi Danau Sentani. Temuan artefak alat batu penokok sagu juga berkaitan dengan subsistensi, yaitu mengkonsumsi sagu. Situs Yomokho sendiri dikelilingi oleh hutan sagu, jika dikaitkan dengan gerabah yang ditemukan, maka gerabah ini berfungsi untuk menyimpan tepung sagu serta merebus air dalam pembuatan papeda.

\section{PENUTUP}

Situs Yomokho merupakan situs pemukiman, dalam penentuan lokasi hunian, manusia pendukung Situs Yomokho mempertimbangkan beberapa hal yaitu diantaranya adalah kondisi tanah, jarak antarhunian. Pemilihan Situs Yomokho sebagai area pemukiman juga mempertimbangkan lokasinya yang dekat dengan sumber bahan makanan (hutan sagu, danau sebagai sumber fauna) dan dekat dengan sumber air (sungai). Pendukung Situs Yomokho memanfaatkan sumber makanan dari lingkungan sekitar.

Untuk mendukung interpretasi yang lebih luas maka perlu dilakukan ekskavasi di lereng bukit sebelah barat bagian bawah. Untuke mengetahui asal usul gerabah di Situs Yomokho, maka perlu dilakukan analisis laboratorium guna mengetahui kesamaan unsur tanah liat yang terdapat di Bukit Yomokho dengan gerabah. Untuk mengetahui interpretasi yang lebih luas maka perlu untuk dilakukan ekskavasi di beberapa titik di sisi bukit lainnya, terutama pada lereng sebelah barat yang berdekatan dengan hutan sagu. Situs Yomokho berpotensi wisata guna mendukung event Festival Danau Sentani karena keletakan lokasinya yang dekat, untuk itu perlu dukungan dari berbagai pihak baik itu pemilik hak ulayat, masyarakat dan pemerintah daerah.

$* * * * *$

\section{DAFTAR PUSTAKA}

Binford, Lewis R. 1972. Archaeological Perspective. New York: Seminar Press.

Darmansyah, 2006. Parim di Papua. Dalam Permukiman di Indonesia: Perspektif Arkeologi. Jakarta: Badan Pengembangan Sumberdaya Kebudayaan dan Pariwisata.

Dwiastoro, Anton. 2009. Doors to the Unknown. The Story of Sentani in the Regency of Papua. Jakarta: TSA Komunika.

Said, C.A.H. dan Utomo, Bambang Budi., 2006. Permukiman dalam Perspektif Arkeologi. Dalam Permukiman di Indonesia: Perspektif Arkeologi. Jakarta: Badan Pengembangan Sumberdaya Kebudayaan dan Pariwisata.

Subroto, P. H. 1985. Studi tentang Pola Pemukiman Arkeologi Kemungkinan-Kemungkinan Penerapannya di Indonesia. PIA III. Jakarta: Pusat Penelitian Arkeologi Nasional.

Suroto, Hari.2010. Prasejarah Papua. Denpasar: Udaya University Press.

Suroto, Hari, Erlin N. I. Djami, M. Irfan Mahmud. 2011. Ekskavasi dan Survei Arkeologi Kawasan Danau Sentani. Laporan Penelitian Balai Arkeologi Jayapura.

Pusat Penelitian dan Pengembangan Arkeologi Nasional. 2008. Metode Penelitian Arkeologi. Jakarta: Puslitbangarkenas.

Tim Penelitian. 2010. Penelitian Arkeologi di Kawasan Danau Sentani. Laporan Penelitian. Jayapura: Balai Arkeologi Jayapura.

Wiradnyana, Ketut. 2011. Prasejarah Sumatera Bagian Utara: Kontribusinya pada Kebudayaan Kini. Jakarta: Yayasan Pustaka Obor Indonesia. 